J. Clin. Chem. Clin. Biochem.

vol. 16, 1978, pp. 607-612

\title{
The Major Fraction of Deoxyribonuclease Activity from Human Urinary Proteins
}

\section{Purification and Properties}

By B. Schmidt, S. Peil and R. K. Zahn

Institute of Physiological Chemistry, Johannes Gutenberg University, 6500 Mainz, Federal Republic of Germany

(Received March 15/June 12, 1978)

Summary: The major fraction of deoxyribonuclease activity from human urinary protein was purified 40 -fold in about $14 \%$ yield. The enzyme shows an isoelectric point at pH 4.2 and has a molecular weight of 33,600 $\pm 3,000$. Optimum activity was shown at $\mathrm{pH} 6.8$ in the presence of $12.5 \mathrm{mmol} / 1 \mathrm{Mg}^{2+}$ plus $1 \mathrm{mmol} / \mathrm{C} \mathrm{Ca}^{2+}$.

The enzymic reaction is inhibited by high ionic strength $\left(>300 \mathrm{mmol} / \mathrm{Na}^{+}\right)$. The purified enzyme readily hydrolyzes native DNA to oligodeoxyribonucleotides with an average chain length of $5.3 \pm 0.2$ after exhaustive digestion. Therefore, this endonuclease may be designated as neutral deoxyribonuclease (deoxyribonucleate oligonucleotidohydrolase, EC 3.1.4.5).

Die Desoxyribonuclease mit der höchsten Enzymaktivität aus menschlichem Harn: Reinigung und Eigenschaften

Zusammenfassung: Aus menschlichem Harn wurde die Hauptfraktion der Desoxyribonucleaseaktivität 40-fach angereichert in einer Ausbeute von 14\%. Das Enzym hat einen I. P. von 4,2 und ein $\mathrm{M}_{\mathrm{r}}$ von $33.600 \pm$ 3.000. Das Aktivitätsoptimum liegt bei pH 6,8 unter Zusatz von $12,5 \mathrm{mmol} / 1 \mathrm{Mg}^{2+}$ und $1 \mathrm{mmol} / \mathrm{C} \mathrm{Ca}^{2+}$.

Native DNA wird bevorzugt abgebaut und als Endprodukte fallen Oligonucleotide mit einer mittleren Kettenlänge von 5,3 $\pm 0,2$ an. Das Enzym wurde als Endonuclease eingeordnet (EC 3.1.4.5).

\section{Introduction}

Deoxyribonucleases (DNases) and other types of nucleolytic enzymes are widely distributed in nature.

Several laboratories have described DNase activities from human tissues, e. g. placenta (1), pancreas (2), epidermis $(3,4)$ and from cultured cells, e. g. HeLa cells $(5-8)$ and fibroblasts $(9,10)$.

Furthermore, DNases were found in human body fluids, such as serum (11) urine (12), seminal plasma $(13,14)$, and liquor cerebrospinalis $(15,16)$.

Electrophoretic patterns of DNase activities from human body fluids have been published for serum (17), urine (18), seminal plasma (19) and liquor cerebrospinalis (20). Based on the electrophoretic data, the present study reports the isolation of the major fraction of DNase activity from human urine.

\section{Materials and Methods}

DNA from herring sperm ${ }^{1}$ ) was prepared according to the procedure of Zahn et al. (21). Yeast RNA was purchased from C. F. Boehringer \& Co (Mannheim/FRG).

Sephadex G-10, G-75 and G-100, dextran blue 2000, DEAE Sephadex A-25 and SE Sephadex C-50 were products of Pharmacia (Uppsala/Sweden). The proteins used as standards in the estimation of the molecular weight of human urinary DNase were obtained as a protein calibration kit from C. F. Boehringer (Mannheim/FRG).

Bovine serum albumin for DNase assay was obtained from Serva (Heidelberg/FRG), $p$-nitrophenyl phosphate as the disodium salt was purchased from E. Merk (Darmstadt/FRG), $p$-nitrophenyl thymidine $5^{\prime}$-phosphate and its $3^{\prime}$-isomer as the sodium or ammonium salt were purchased from Calbiochem (Los Angeles/Ca. 90054/USA). Chemicals required for gel electrophoresis were from E. Merck (Darmstadt/FRG), Ampholine, pH 3.5-10, was a product of LKB Produkter AB (Stockholm/Sweden). 1) Herring sperm DNA was a gift of H. Mack (Illertissen/Bay./
FRG). 
The enzymes used were from C. F. Boehringer (Mannheim/FRG), alkaline phosphatase from calf intestine, snake venom phosphodiesterase from Crotalus terr. terr., and spleen phosphodiesterase.

\section{DNase assay}

a) Enzyme activity was generally estimated by the hyperchromicity method of Kunitz (22). $1 \mathrm{mU}=$ increase of $0.001 \mathrm{~A}_{260}$.

b) DNase activity embedded in polyacrylamide gels was determined by the methyl-green DNA decolorization test $(11,23)$.

c) Disc electrophoresis of DNase was performed as described by Ornstein (24) and Davis (25). After the electrophoretic run the gels were developed according to Boyd \& Mitchell (26).

\section{Molecular weight determination}

Two different methods were applied in order to determine the molecular weight of the DNase: sucrose gradient centrifugation (27) and gel filtration (28).

\section{Estimation of the isoelectric point of the DNase}

The electrofocusing procedure was performed according to Catsimpoolas (29).

\section{DNase Digestion}

The mode of nucleolytic attack was investigated by gel filtration of the digests on Sephadex G-100 according to Birnboim (30). Furthermore, the hydrolysates were segregated by length according to the procedure of Rushizky et al. (31).

\section{Phosphodiesterase Digestion}

The reaction mixture (total volume, $1 \mathrm{ml}$ ) contained $100 \mu \mathrm{l}$ of enzyme (diluted 1:600) and a final substrate concentration of $0.15 \mathrm{mmol} / 1 \mathrm{DNA}$ phosphorus in $50 \mathrm{mmol} / 1 \mathrm{Tris} / \mathrm{HCl}$ buffer, $\mathrm{pH}$ 8.5. Conditions for incubation were room temperature, overnight. Estimation of total phosphorus according to 1. c. (32).

Release of phosphatase-sensitive phosphorus

300- $\mu$ l samples were supplemented with $20 \mu \mathrm{l}$ of $1 \mathrm{~mol} / 1$ Tris/

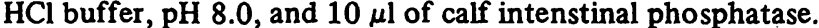
Incubation was carried out at $37^{\circ} \mathrm{C}$ for $30 \mathrm{~min}$

\section{Assays for contaminant enzymes}

The activities of ribonuclease, phosphodiesterase and phosphatase were measured as described earlier (33).

Estimation of protein

Protein concentration was measured according to Lowry et al. (34).

\section{Results}

\section{Purification of the enzyme}

All preparations were performed at $4^{\circ} \mathrm{C}$.

\section{Step I: Preparation of the raw concentrate}

30 liters of freshly collected samples of urine were made $0.2 \mathrm{~g} / 1$ with respect to sodium azide, supplemented with EDTA to a final concentration of $10 \mathrm{mmol} / 1$, adjusted to $\mathrm{pH} 7.0$, and diluted with an equal volume of distilled water. $10 \mathrm{ml}$ of DEAE Sephadex A-25 (equilibrated with $50 \mathrm{mmol} / 1 \mathrm{Tris} / \mathrm{HCl}$ buffer, $\mathrm{pH} 7.0$, containing $10 \mathrm{mmol} / 1$ EDTA) were added and the slurry was stirred for 12 hours. The batchwise processing with DEAE Sephadex was repeated two times with newly added DEAE Sephadex. The collected sediments were eluted three times with $60 \mathrm{ml}$ of $300 \mathrm{mmol} / 1 \mathrm{NaCl}$ containing $3 \mathrm{mmol} / 1 \mathrm{CaCl}_{2}$. The extracts (total volume, $180 \mathrm{ml}$ ) were concentrated against polyethylene glycol. This step I preparation was allowed to stand in the deep-freeze $\left(-20^{\circ} \mathrm{C}\right)$. When thawed after 6 weeks, the samples showed a $12 \%$ loss of enzymic activity.

\section{Step II: Gel filtration on Sephadex G-10}

The gel was equilibrated with $5 \mathrm{mmol} / \mathrm{l}$ sodium acetate buffer, pH 6.85. $6 \mathrm{ml}$ of the crude extract (Step I) were applied to the column $(3.6 \times 23 \mathrm{~cm})$ which then was washed with $190 \mathrm{ml}$ of the same buffer at a flow rate of $120 \mathrm{ml}$ per hour. The active fractions, made $100 \mathrm{~g} / \mathrm{l}$ with respect to sorbitöl (Karion F), represent Step II.

\section{Step III: Chromatography on SE Sephadex C-25}

The gel was equilibrated with $5 \mathrm{mmol} / \mathrm{l}$ sodium acetate buffer, pH 4.7 containing $100 \mathrm{~g} / \mathrm{l}$ of sorbitol.

The Step II solution was adjusted to $\mathrm{pH} 4.7$ and placed on the column $(1.5 \times 12 \mathrm{~cm})$, and the fractions containing the major enzymic activity appeared in the flowthrough. These fractions were supplemented with $5 \mathrm{mmol} / \mathrm{l} \mathrm{CaCl} \mathrm{Cl}_{2}$. After a 3-hour period the solution was brought to final concentration of $50 \mathrm{mmol} / 1 \mathrm{Tris} / \mathrm{HCl}$, $\mathrm{pH}$ 6.5, and permitted to stand overnight (Step III fraction).

\section{Step IV: First chromatography on DEAE Sephadex} A-25

DEAE Sephadex was equilibrated with $50 \mathrm{mmol} / 1$ Tris/ $\mathrm{HCl}$ buffer, $\mathrm{pH} 7.0$, containing $50 \mathrm{mmol} / 1 \mathrm{EDTA}$, pH 7.0, and finally equilibrated with $50 \mathrm{mmol} / 1 \mathrm{Tris} / \mathrm{HCl}, \mathrm{pH} \mathrm{7.0,}$ containing $10 \mathrm{~g} / 1$ sorbitol. The Step III solution was supplemented with $10 \mathrm{mmol} / 1$ EDTA, adjusted to $\mathrm{pH} \mathrm{7.0,}$ and applied to a column $(1.5 \times 10 \mathrm{~cm})$ of DEAE Sephadex A-25. After loading, the column was washed with the final equilibrating buffer containing $75 \mathrm{mmol} / 1 \mathrm{NaCl}$. The enzyme activity was eluted at a reduced flow rate of $20 \mathrm{ml} / \mathrm{h}$ with the processing buffer, after addition of $\mathrm{NaCl}$ and $\mathrm{CaCl}_{2}$ to final concentrations of $150 \mathrm{mmol} / \mathrm{l}$ and $3 \mathrm{mmol} / \mathrm{l}$, respectively. The fractions containing enzyme activity were pooled, stabilized by adding DNA and $\mathrm{MgCl}_{2}$ to final concentrations of $1 \mathrm{mg} / \mathrm{l}$ and $5 \mathrm{mmol} / \mathrm{l}$ respecitvely, and designated as Step IV.

\section{Step V: Lyophilization}

The Step IV fraction was dialysed for 24 hours against two changes of distilled water (6 liter) and subsequently freeze-dried.

\section{Stepp VI: Filtration on Sephadex G-75}

The Step V lyophilisate was redissolved in $50 \mathrm{mmol} / 1$ ammonium formate buffer, $\mathrm{pH} 7.0$, and chromatogra- 
phed on a Sephadex G-75 column $(5 \times 20 \mathrm{~cm})$. Fractions containing enzymic activity were designated as Step VI.

\section{Step VII: Second chromatography on DEAE Sephadex A-25}

The Step VI solution was applied to a DEAE Sephadex column $(0.8 \times 6 \mathrm{~cm})$ equilibrated with $50 \mathrm{mmol} / 1$ ammonium formate buffer, $\mathrm{pH}$ 7.0. Elution was carried out with a linear gradient (total volume, $140 \mathrm{ml}$ ) of ammonium formate from 50 to $500 \mathrm{mmol} / \mathrm{l}$. The eluted samples of enzymic activity were stored in a deep freeze (Step VII fraction).

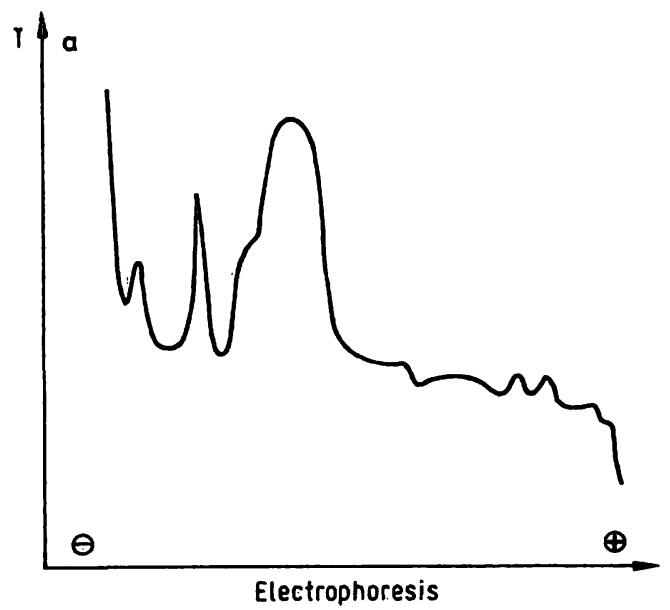

Step VII fraction was used for the experiments described. The course of a typical fractionation (of a four-fold assay) is detailed in table 1.

\section{Properties of the enzyme}

After electrophoresis, the stage VII preparation produced only a single sharp band of DNase activity (see fig. 1, b). By incubation of the purified DNase solution over a 24 hour period evidence was obtained that the DNase preparation is devoid of phosphomonoesterase and phosphodiesterase activities. Traces of ribonuclease activity both

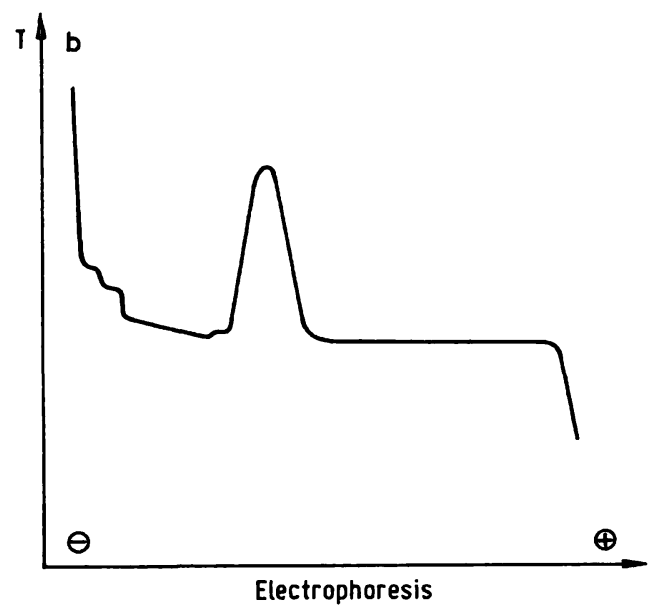

Fig. 1. Densitometer tracings of methyl-green DNA-containing polyacrylamide gels after electrophoresis, incubation and staining of the separated urinary DNase activity at different stages of the purification procedure. The gel contained $0.2 \mathrm{mg}$ methyl-green DNA per $\mathrm{ml}$ of $150 \mathrm{~g} / \mathrm{l}$ polyacrylamide running gel at $\mathrm{pH}$ 8.7. For experimental conditions, see Methods.

a) Scanning of DNase activity from native urine;

b) Tracing of DNase pheretogram from Step VII solution.

The direction of electrophoresis is indicated by the arrow on the abscissa; the ordinate shows transmittance.
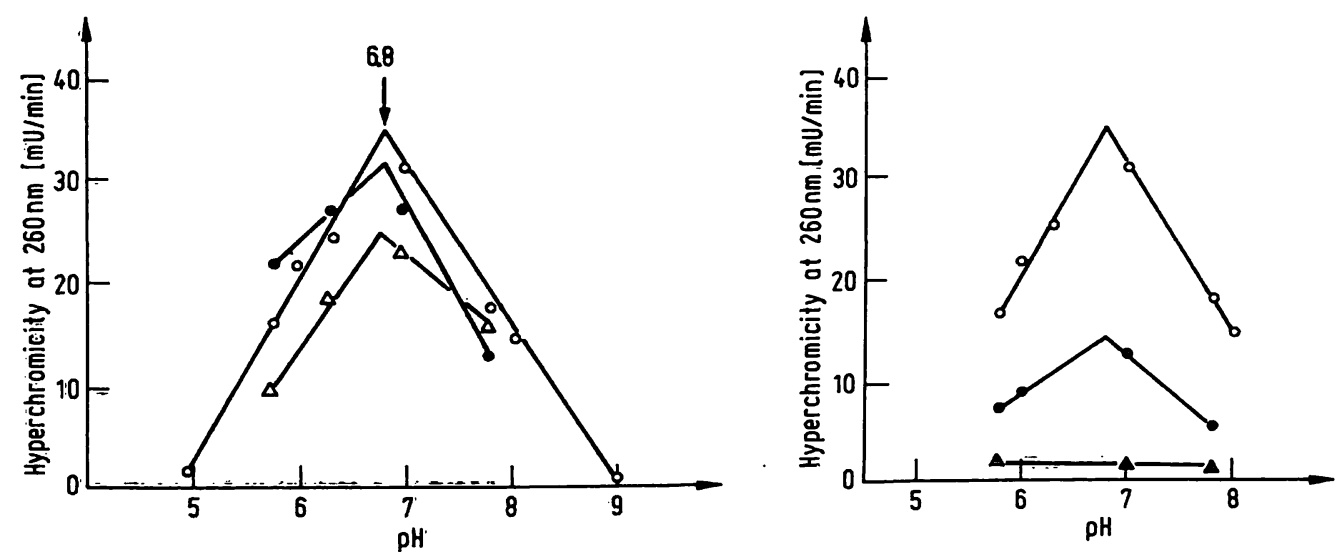

Fig. 2. The effect of pH on the hyperchromicity at $260 \mathrm{~nm}$ induced by the urinary DNase.

Enzyme activity against native DNA was measured in the standard assay system except that the pH varied with different buffers added. The buffers used were sodium citrate for $\mathrm{pH}$ values ranging from 3-4, sodium acetate for $\mathrm{pH}$ values ranging from $4-6$, Tris/ $\mathrm{HCl}$ for $\mathrm{pH}$ values ranging from $7-8$, and sodium borate for $\mathrm{pH}$ values ranging from 9-10 with a final concentration of $50 \mathrm{mmol} / \mathrm{l}$, respectively.

(left) $\mathrm{pH}$ optimum with a constant $\mathrm{Na}^{+}$concentration of $50 \mathrm{mmol} / \mathrm{l}$ and varying $\mathrm{Mg}^{2+}$ concentration, $-\Delta-=1 \mathrm{mmol} / \mathrm{l}$; $-0-=3 \mathrm{mmol} / \mathrm{l} ;---=10 \mathrm{mmol} / \mathrm{l}$; (right) $\mathrm{pH}$ optimum with $3 \mathrm{mmol} / 1 \mathrm{Mg}^{2+}$ and variable $\mathrm{Na}^{+}$concentrations; $-0-$, $50 \mathrm{mmol} / \mathrm{l} ;-\bullet-, 100 \mathrm{mmol} / \mathrm{l} ;-\wedge-, 300 \mathrm{mmol} / \mathrm{l}$. 
Tab. 1. Purification procedure

\begin{tabular}{|c|c|c|c|c|}
\hline Step & $\begin{array}{l}\text { Volume } \\
\text { (ml) }\end{array}$ & $\begin{array}{l}\text { Total } \\
\text { protein } \\
(\mathrm{mg})\end{array}$ & $\begin{array}{l}\text { Total } \\
\text { activity } \\
\text { (mUnits) }\end{array}$ & $\begin{array}{l}\text { Specific } \\
\text { activity } \\
\text { (mUnits/mg) }\end{array}$ \\
\hline $\begin{array}{l}\text { I Crude concen- } \\
\text { trate }\end{array}$ & 22.5 & *) & 136 & \\
\hline $\begin{array}{l}\text { II Sephadex G-10 } \\
\text { gel filtration }\end{array}$ & 440 & 68 & 135 & 2.0 \\
\hline $\begin{array}{l}\text { III SE Sephadex } \\
\text { chromatography }\end{array}$ & 468 & 70 & 49 & 0.7 \\
\hline $\begin{array}{l}\text { IV First DEAE } \\
\text { Sephadex } \\
\text { chromatography }\end{array}$ & 433 & 41 & 34 & 0.8 \\
\hline V Lyophilisate & 2.8 & & 37 & \\
\hline $\begin{array}{l}\text { VI Sephadex G-75 } \\
\text { gel filtration }\end{array}$ & 95 & 0.6 & 31 & 54.2 \\
\hline $\begin{array}{l}\text { VII Second DEAE } \\
\text { Sephadex } \\
\text { chromatography }\end{array}$ & 61 & 0.2 & 18 & 83.6 \\
\hline
\end{tabular}

*) correct protein estimation could not be carried out in the presence of the accompanying material.

at $\mathrm{pH} 5.8$ and $\mathrm{pH} 8.0$ were detectable. The purified DNase activity was remarkably stable against heat inactivation at $\mathrm{pH} 7$ up to $50^{\circ} \mathrm{C}$. The molecular weight of the urinary DNase was estimated to 33,600 (table 2).

Applying the electrofocusing method (29) the isoelectric point obtained is at $\mathrm{pH} 4.2$.

The DNase exhibits maximum activity at pH 6.8 (fig. 2). At a final DNA concentration of $100 \mu \mathrm{g}$ per ml, the optimum $\mathrm{Mg}^{2+}$ concentration is $3.3 \pm 0.1 \mathrm{mmol} / 1$ at $\mathrm{pH} 7$. The addition of $1 \mathrm{mmol} / 1 \mathrm{Ca}^{2+}$ shifts the optimum $\mathrm{Mg}^{2+}$ concentration to $12.5 \mathrm{mmol} / \mathrm{l}$. In order to determine whether the enzyme functions in an endo- or exonucleolytic fashion, the enzymic digestion of DNA was followed as described by Birnboim (30). Based on the elution patterns presented in figure 3 the DNase should be classified as an endonuclease.

After exhaustive digestion the hydrolyzate of DNA was chromatographed on DEAE-Sephadex. The elution pattern as presented in figure 4 shows discrete peaks up to pentamers and a non-resolved portion of large-sized oligomers.

Tab. 2. Comparison of average molecular weight of deoxyribonuclease from human urine as determined by two methods

\begin{tabular}{|c|c|c|}
\hline Methods and standard proteins & $\begin{array}{l}\text { Molecular } \\
\text { weight }\end{array}$ & Average \\
\hline $\begin{array}{l}\text { Sucrose density centrifugation } \ldots \ldots \\
\text { cytochrome c } \ldots \ldots \\
\text { chymotrypsinogen } \ldots \ldots \\
\text { ovalbumin } \ldots \ldots \\
\text { bovine serum albumin } \ldots\end{array}$ & $\begin{array}{l}28,600 \\
29,250 \\
36,000 \\
36,450\end{array}$ & 32,580 \\
\hline $\begin{array}{l}\text { Sephadex gel filtration*) } \ldots \ldots \\
\text { Average of the two methods } \ldots \ldots\end{array}$ & & $\begin{array}{l}34,680 \\
33,600\end{array}$ \\
\hline
\end{tabular}

*) for proteins used as standards, see Methods
Evaluating the time course of DNase attack the average chain length of the fragments was decreasing from $28 \pm$ 4 at $30 \mathrm{~min}$ to $5.3 \pm 0.2$ at $24 \mathrm{~h}$.
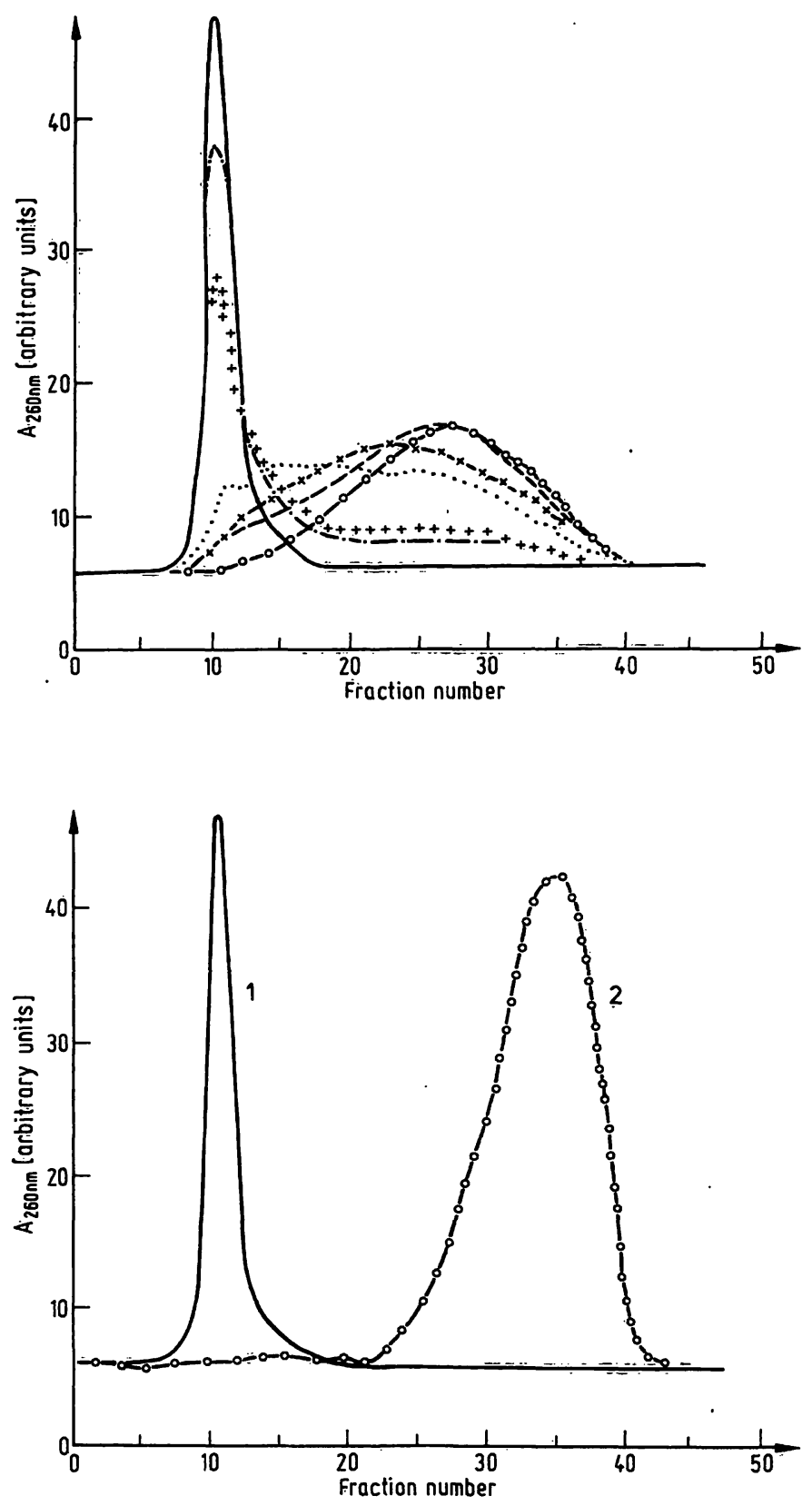

Fig. 3. Chromatography on Sephadex G-100 of native DNA at different stages during its digestion with DNàse. The column $(1.5 \times 23.5 \mathrm{~cm})$ was packed with Sephadex G-100 and $1 \mathrm{ml}$ Sephadex $\mathrm{G}-10$ was layered onto its surface. Equilibration was performed with $50 \mathrm{mmol} / \mathrm{l}$ ammonium formate buffer, $\mathrm{pH}$ 7.0. Incubation mixture (total volume, $10 \mathrm{ml}$ ) contained $2 \mathrm{mg}$ of native DNA in $50 \mathrm{mmol} / 1 \mathrm{Tris} / \mathrm{HCl}$ buffer, $\mathrm{pH} 7.0,25 \mathrm{mmol} / 1 \mathrm{Mg}^{2+}$ and $1 \mathrm{mmol} / 1 \mathrm{Ca}^{2+}$, and $1 \mathrm{ml}$ of enzyme (Step VII fraction). The elution patterns shown in the upper graphs were of $1 \mathrm{ml}$ aliquots of the reaction mixture when incubated at $37^{\circ} \mathrm{C}$ for (a) $-, 5 \mathrm{~min},(\mathrm{~b})-.-, 20 \mathrm{~min},(\mathrm{c})+++30 \mathrm{~min}$, (d) ..., $60 \mathrm{~min}$, (e) $x-x, 90 \mathrm{~min},(f)-=, 180 \mathrm{~min}$, and (g) $--\rightarrow, 240 \mathrm{~min}$. Incubation was stopped by making the sample $3 \mathrm{~mol} / \mathrm{l}$ with respect to $\mathrm{NaCl}$. Elution was performed with the equilibrating buffer. In the lower graph the elution pattern of a mixture of $400 \mu \mathrm{g}$ of native DNA (1) and $400 \mu \mathrm{g}$ of dCMP plus $250 \mu \mathrm{g}$ of dGMP (2) is shown. 


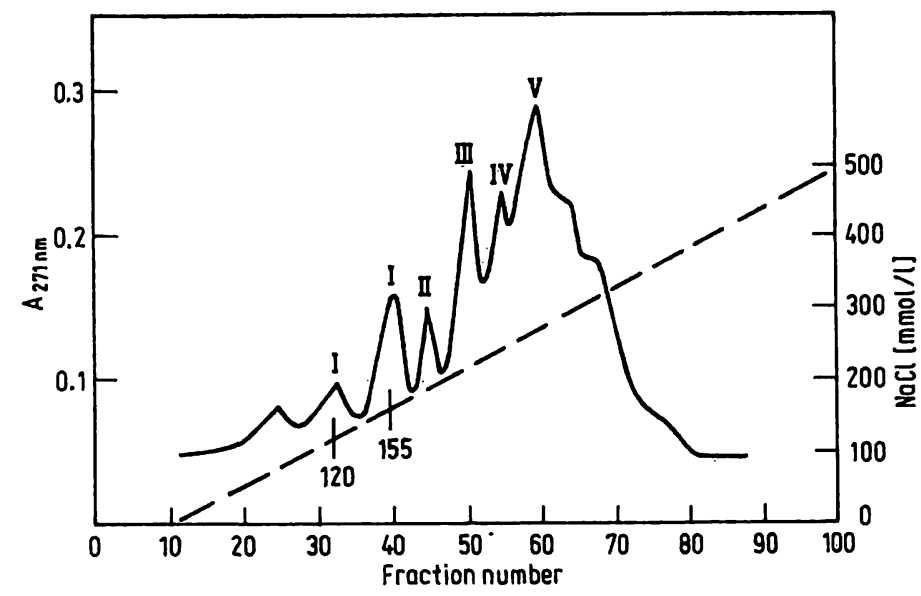

Fig. 4. Elution profile of hydroly sate of DNA extensively digested with human DNase, step VII fraction. The reaction mixture (total volume, $10 \mathrm{ml}$ ) containing $10 \mathrm{mmol} / 1 \mathrm{Tris} / \mathrm{HCl}$ buffer, $\mathrm{pH} 7.0,200 \mu \mathrm{g} / \mathrm{ml}$ herring sperm DNA, $12.5 \mathrm{mmol} / 1 \mathrm{Mg}^{2+}$, and $1 \mathrm{mmol} / 1 \mathrm{Ca}^{2+}$ was incubated for $7 \mathrm{~h}$ at $37^{\circ} \mathrm{C}$, diluted with distilled water to a final volume of $30 \mathrm{ml}$ and layered onto a DEAE Sephadex A-25 column $(0.9 \times 29 \mathrm{~cm})$ which had been equilibrated with $10 \mathrm{mmol} / 1 \mathrm{Tris} / \mathrm{HCl}$ buffer, $\mathrm{pH} 7.8$, and $7 \mathrm{~mol} / \mathrm{l}$ urea. After washing with $30 \mathrm{ml}$ of the processing buffer, elution was performed with a linear $\mathrm{NaCl}$ gradient from 0 to $0.5 \mathrm{~mol} / 1 \mathrm{NaCl}$ in the same buffer. The total volume of the gradient was $460 \mathrm{ml}$ and 5 - $\mathrm{ml}$ fractions were collected. Aliquots $(0.2 \mathrm{ml})$ were used both for the estimation of total phosphorus and the phosphorus sensitive to alkaline phosphatase from calf intestine; for details see Methods. The remainder was measured at $271 \mathrm{~nm}$.

The Roman numbers positioned directly above each peak indicate the respective chain length.

Ordinate: (left scale) Absorbance at $271 \mathrm{~nm}$, _-; (right scale) $\mathrm{NaCl}$ gradient mmol/1, - - - ;

In order to obtain information on the position of the terminal phosphate in oligomers from DNase cleavage the hydrolyzate was subsequently digested by means of snake venom and spleen phosphodiesterase, respectively.

Figure 5 illustrates the chromatographic patterns on Sephadex G-100 of digests exhaustively cleaved by DNase (1) and subsequently treated with additional (2) spleen phosphodiesterase or (3) snake venom phosphodiesterase. Evidence could be obtained that the peak of material absorbing at 260 is shifted to regions of lower molecular weight by subsequent treatment of DNase digest with both spleen and venom exonuclease. But, in the case of venom phosphodiesterase the migration to values of lower molecular weights is faster than in the case of the spleen enzyme. Therefore, it may be concluded that the fragments of DNase digestion carry phosphate at the $5^{\prime}$ termini.

\section{Discussion}

The main problem of the purification procedure was the separation of two DNase activities which apparently are very similar. In the tracings of the electrophoretic runs

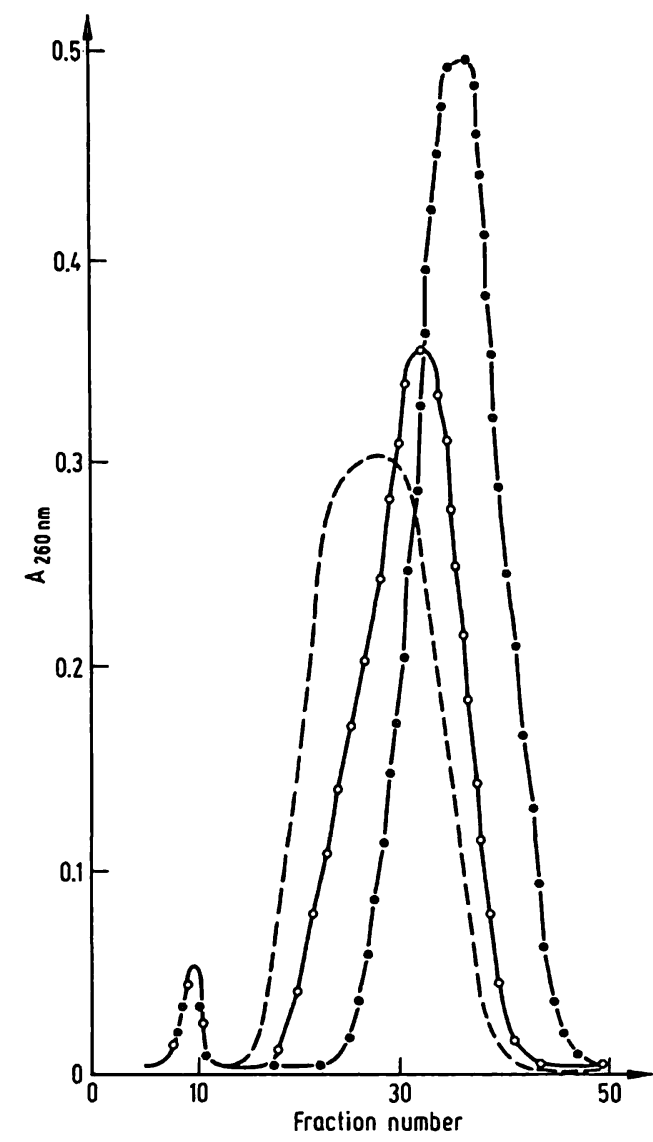

Fig. 5. Chromatography on Sephadex G-100 of cleavage fragments of a combined DNase/phosphodiesterase assay. $10 \mathrm{ml}$ of a DNase incubation mixture were treated as described in Methods except that the incubation period was $7 \mathrm{~h}$. Afterwards the reaction mixture was divided into three 3-ml portions. --- , digest of DNase, without further treatment as control; --- , digest of DNase, plus $10 \mu \mathrm{l}$ snake venom phosphodiesterase, after adjusting to pH 8.0, running over night, room temperature; -0-, DNase digest plus $10 \mu \mathrm{l}$ spleen phosphodiesterase was brought to $\mathrm{pH} 8.0$ and incubation was carried out overnight at room temperature.

For gel filtration a Sephadex G-100 column (1.5 X $23.5 \mathrm{~cm}$ ) was equilibrated with $50 \mathrm{mmol} / 1$ ammonium formate buffer, $\mathrm{pH} 7.0 .1 \mathrm{ml}$ aliquots of the assays specified above were applied separately to the column.

the concomitant DNase component stands out clearly as a shoulder of the main band distinctly recorded in figure 1 , a. We succeeded in solving this problem using SE Sephadex chromatography (Step III) by which the accom: panying component was eliminated from the main fraction. Stage VII of the enzyme preparation produced only a single peak of DNase activity when monitored on disc electrophoresis (fig. 1, b). Different concentrations of Tris/HCl buffer ranging from $20-50 \mathrm{mmol} / 1$ had no apparent influence on the DNase catalyzed reaction, whereas discrete changes in reaction rate due to variations in the concentration of $\mathrm{Na}^{+}$can be shown, using different buffers containing sodium as its acetate, citrate, or borate. This is important, since effects measured in Tris or sodium-containing buffers are only comparable if the Tris-buffered system is supplemented with $\mathrm{Na}^{+}$. 
Since a considerable effect $\mathrm{Na}^{+}$on the rate of reaction has been evidenced, a basic $\mathrm{Na}^{+}$concentration of $50 \mathrm{mmol} / \mathrm{l}$ must be maintained irrespective of the nature of the buffer used. $\mathrm{Na}^{+}$concentrations higher than $300 \mathrm{mmol} / \mathrm{l}$ are strongly inhibitory.

The optimum incubation conditions established for the assay of the enzyme are $0.3 \mathrm{mmol} / 1 \mathrm{DNA}$ phosphorus, $\mathrm{pH} 6.8$, in the presence of $12.5 \mathrm{mmol} / \mathrm{Mg}^{2+}$ plus $1 \mathrm{mmol} / \mathrm{l}$ $\mathrm{Ca}^{2+}$. It is interesting to note that a similar interdependence between $\mathrm{Ca}^{2+}$ and $\mathrm{Mg}^{2+}$ concentration has been described by another laboratory for bovine pancreatic DNase I (35-37). The human urinary DNase attacks preferently native DNA and degrades the substrate, after exhaustive digestion, to oligomers of an average chain length of around 5, indicating that it acts as an endonuclease. Since snake venom phosphodiesterase degrades the oligomers of the DNase digest to monodeoxynucleotides faster than spleen phosphodiesterase, it may be suggested that the oligomers are characterized by a phosphorylated 5' terminus $(38,39)$.

The DNase is devoid of phosphodiesterase and phosphomonoesterase activities and only trace amounts of RNase activity are detectable. The urinary DNase described in this paper exhibits some common properties with mammalian pancreatic DNase I and may be classified as a neutral deoxyribonuclease (deoxyribonucleate oligonucleotidohydrolase, EC 3.1.4.5). Despite these similarities, it may not be assumed that this enzyme is identical with that of pancreatic origin.

\section{Acknowledgement}

This work was supported in part both by Deutsche Forschungsgemeinschaft and Fonds der Chemischen Industrie.

We thank Mrs. I. Nagel for typing the manuscript.

\section{References}

1. Doniger, J. \& Grossman, L. (1976), J. Biol. Chem. 251, 4579-4587.

2. Funakoshi, A., Tsubota, Y., Wakasugi, H., Ibayashi, H. \& Takagi, Y. (1977), J. Biochem. Tokyo 82, 1771-1779.

3. Jarret, A. (1967), J. Invest. Dermatol. 49, 443-448.

4. Winter, V. \& Freund, D. (1969), J. Invest. Dermatol. 52, 344-347.

5. Burt, D. H. \& Brent, T. P. (1971), Biochem. Biophys. Res. Commun. 43, 1382-1387.

6. Slor, H. (1973), Biochem. J. 136, 83-87.

7. Slor, H., Buston, H. \& Lev. T. (1973), Biochem. Biophys. Res. Commun. 52, 556-561.

8. Studzinski, G. P. \& Churchill, J. R. (1971), Fed. Proc., Fed. Am. Soc. Exp. Biol. 30, 292.

9. Duker, N. J. \& Teebor, G. W. (1975), Nature (London) 255, $82-84$.

10. Teebor, G. W. \& Duker, N. J. (1975), Nature (London) 258, 544-547.

11. Kurnick, N. B. (1950), Arch. Biochem. Biophys. 29, 41-53.

12. Kowlessar, O. D., Okada, S., Potter, J. L. \& Altmann, K. J. (1957), Arch. Biochem. Biophys. 68, 231.

13. Quinn, P. J. (1968), J. Reprod. Fertil. 17, 35-41.

14. Zamenhof, S., Shettles, L. B. \& Chargaff, E. (1950), Nature (London) 165, 765.

15. Healy, J. W. (1964), J. Neurochem. 11, 119-123.

16. Kovacs, E. (1954), J. Pediatr. 45, 569-574.

17. Zöllner, E. J., Heicke, B. \& Zahn, R. K. (1974), Anal. Biochem. 58, 71-76.

18. Zöllner, E. J., Müler, W. E. G., Zahn, R. K., Brehm, G. \& Korting, G. W. (1971), Klin. Wochenschr. 49, 1290-1294.

19. Zöllner, E. J., Lachner, H. \& Zahn, R. K. (1973), Z. Naturforsch $28 C, 742-746$.
20. Zöllner, E. J. \& Zahn, R. K. (1973), diese Z. 11, 117-120.

21. Zahn, R. K., Tiesler, E., Kleinschmidt, A. K. \& Lang, D. (1962), Biochem. Z. 336, 281-298.

22. Kunitz, M. (1950), J. Gen. Physiol. 33, 349-362.

23. Horney, D. L. \& Webster, D. A. (1971), Biochịm. Biophys. Acta 247, 54-61.

24. Ornstein, L. (1964), Ann. N.Y. Acad. Sci. 121, 321-349.

25. Davis, B. J. (1964), Ann. N. Y. Acad. Sci. 121, 404-427.

26. Boyd, J. B. \& Mitchell, H. K. (1965), Anal. Biochem. 13, $28-42$.

27. Martin, R. G. \& Ames, B. N. (1961), J. Biol. Chem. 236, 1372-1379.

28. Andrews, P. (1964), Biochem. J. 91, 222-233.

29. Catsimpoolas, N. (1968), Anal. Biochem. 26, 480-482.

30. Birnboim, H. (1966), Biochim. Biophys. Acta 119, 198-200.

31. Rushizky, G. W., Bartos, E: M. \& Sober, H. A. (1964), Biöchemistry 3, 626-629.

32. Ames, B. N. (1966), Methods Enzymol. 8, 115-118.

33. Breter, H.-J., Schmidt, B. \& Zahn, R. K. (1975), Enzyme $19,149-153$.

34. Lowry, O. H., Rosebrough, N. J., Farr, A. L. \& Randail, R. J. (1951), J. Biol. Chem. 193, 265-275.

35. Price, P. A. (1975), J. Biol. Chem. 250, 1981-1986.

36. Douvas, A. \& Price, P. A. (1975), Biochim. Biophys. Acta 395, 201-212.

37. Shack, J. \& Bynum, B. S. (1964), J. Biol. Chem. 239, 3843-3848.

38. Richards, G. M. \& Laskowski, sr., M. (1969), Biochemistry $8,1786-1795$.

39. Ho, N. W. Y. \& Gilham, P. T. (1973), Biochim. Biophys. Acta $308,53-58$.
Prof. Dr. Dr. B. Schmidt Physiologisch-Chemisches Institut der Johannes-Gutenberg-Universität Duesbergweg 6500 Mainz 